\title{
European sturgeon (Acipenser sturio L.) young of the year performance in different rearing environments -study within a stocking program
}

\author{
Erika Carrera-García • Eric Rochard • \\ Marie-Laure Acolas
}

Received: 14 March 2016 / Accepted: 23 September 2016/Published online: 5 October 2016

(C) The Author(s) 2016. This article is published with open access at Springerlink.com

\begin{abstract}
The European sturgeon is critically endangered and the French ex-situ conservation approach involves developing a captive stock to produce offspring for release to boost natural populations. The purpose of our study was to assess the effects of rearing environment before stocking on the survival, growth, and behavior of threemonth-old sturgeons from two different crossings. Enriched rearing was designed to mimic the variability of the natural environment using river water, natural photoperiod, substrate, variable water current and depths. Traditional rearing was carried out with bare tanks, underground water, dark conditions, without current and at constant depth. Fish survival was determined monthly and growth was estimated weekly. Behavior was assessed with exploration and novel prey tests in solitary using video tracking. Results demonstrated that enriched condition resulted in bigger fish from the first month. Growth curve analysis revealed that enriched environment made both fish crossings grow in a similar manner. In contrast, crossings growth differed in traditional rearing which may reflect a genotype-environment interaction. Behavioral data highlighted that enriched-reared fish were slower to
\end{abstract}

E. Carrera-García · E. Rochard · M.-L. Acolas

EABX, Aquatic Ecosystems and Global Changes Research Unit, Diadromous migratory fish team, IRSTEA, National Research Institute of Science and Technology for Environment and Agriculture, 33612 Cestas, France

E. Carrera-García $(\bowtie)$

Department of Biological Sciences, Pontificia Universidad Católica del Ecuador, 170525 Quito, Ecuador

e-mail: erika.carrera-garcia@irstea.fr explore a new environment but more individuals engaged on doing so than traditional-reared fish. Results also showed that survival was high $(>80 \%)$ during all the trial. However, survival was lower during the second month in enriched environment. Our findings advocate for the integration of enriched rearing practices within the juvenile production for release in order to boost the performance linked to fitness. Stocking practices and life history research must work together to favor adaptive aquaculture approaches, which support species conservation.

Keywords Stocking · Sturgeon · Survival · Growth • Behavior $\cdot$ Rearing conditions

\section{Introduction}

Most of the 25 species of sturgeons are believed to be at risk (Birstein 1993; Billard and Lecointre 2000), and $72 \%$ of the family are considered "endangered" or "critically endangered" according to the IUCN status (IUCN 2015). Many species benefit from specific conservation measures, such as habitat restoration and protection, fishing regulations, and specific targeted stocking practices (Waldman and Wirgin 1998; Jackson et al. 2002; Arlati and Poliakova 2009; Maltsev 2009; Williot et al. 2009). The European sturgeon, Acipenser sturio (Linnaeus, 1758) is a critically endangered migratory species (Lepage and Rochard 1995; Lassalle et al. 2010; Chassaing et al. 2016) which is currently the subject of a European recovery plan (Rosenthal et al. 2007), along with national action plans in France (MEDDTL 2011) 
and in Germany (Gessner et al. 2010). The species has a complex life cycle involving migration periods associated with habitat shifts (Castelnaud et al. 1991; Rochard et al. 2001; Acolas et al. 2011a, 2012). The reproduction occurs in rivers between May and June, following which juveniles migrate to estuaries in the first year of their life. They then remain and grow in estuaries for several years. Sturgeons adopt a nomadic lifestyle by foraging within estuarine and marine habitats until finally leaving the estuary to further grow at sea before coming back to the river to breed. However, knowledge about young stages of this species in the wild is limited (Acolas et al. 2011b). The specific needs of this migratory species with regard to habitat, as well as vulnerability during migration, due to overfishing and habitat degradation are major factors involved in population collapse over the past few decades (Rochard et al. 1990). One species restoration action consists of developing a captive stock to produce offspring for release in river systems in an attempt to boost natural populations (Chebanov et al. 2011; IUCN/SSC 2013).

Elasticity analyses which calculate the potential to increase a population provided the highest values for the young of the year stage (Gross et al. 2002). Indeed, while this age-class suffers from the highest natural mortality rate, there could be a recovery of declining populations if vital rates such as growth, survival and migration capacities during early stages were increased (Secor et al. 2002). This aspect highlights the importance of hatcheries in conservation programs, since captive fish survival rates in early life stages can be significantly greater than those found in the wild (Secor et al. 2002). Therefore, stocking practices should consider knowledge provided by studies of early life history in order to develop creative and adaptive aquaculture approaches that will allow support for better species conservation (Chebanov et al. 2002; Secor et al. 2002). This type of research-based approach in aquaculture is a promising avenue for sturgeon conservation. Generally, major concerns of stocking for conservation purposes focused on the impact of genetic drift (Busack and Currens 1995; Campton 1995; Yokota et al. 2003), introgression (Susnik et al. 2004; Lamaze et al. 2012) and genotypic fitness (Zhu et al. 2002; Aprahamian et al. 2003; Jager 2005) on wild populations. Nowadays, rearing environment of hatchery fish for stocking purposes is a subject raising attention (Brown et al. 2003;
Strand et al. 2010; Roberts et al. 2011; Bergendahl et al. 2016) because artificial environments may induce behavioral responses different from those expected in wild fish (Johnsson et al. 2014). Indeed, hatcheries often expose the fish to selective reproduction and early life experiences in a safe setting, which could strongly influence the behavioral (Brown et al. 2003; Klefoth et al. 2012), genetic, morphological and physiological attributes necessary to respond adequately to natural conditions after stocking (Brown et al. 2003; Braithwaite and Salvanes 2005). In other words, artificial selection enacted in hatchery conditions will produce fish suited to that environment, but which may be not well suited to face life in the wild. Fitness value, defined as the ability of an individual to survive and reproduce in a particular environment (MaynardSmith 1989), is difficult to quantify in nature (Arnold 1983). Instead, some traits, such as growth (Huusko and Vehanen 2011), swimming capacity (Adams et al. 1997; Adams et al. 1999), foraging abilities (Brown et al. 2003; Massee et al. 2007), and the ability to detect and escape predators (Alvarez and Nicieza 2003; De Mestral and Herbinger 2013) are used as alternative predictors, which can be measured in controlled conditions (Arnold 1983). When comparing these fitnessrelated traits in hatchery and wild-born fish, the former often show behavioral deficiencies, such as reduced territorial and feeding efficiency (Aarestrup et al. 2005), reduced anti-predatory responses and social interactions (Salvanes and Braithwaite 2006), reduced reproductive success in the wild (Araki et al. 2008), risk taking behavior (Sundström and Johnsson 2001; Stamps 2007), increased vulnerability towards angling (Klefoth et al. 2012) than in wild fish. These deficits may lead to poor postrelease survival (Aarestrup et al. 2005; Braithwaite and Salvanes 2005). However, exposing the fish to variability during early stages, also called an "enriched environment", can reduce such deficiencies (Braithwaite and Salvanes 2005; Kotrschal and Taborsky 2010; Roberts et al. 2014). Enriched conditions are characterized by increased habitat complexity (Braithwaite and Salvanes 2005; Johnson et al. 2014), often mimicking the instability of natural habitats in photoperiod, temperature, prey availability, visual and spatial cues, and could be considered as a "training" approach that would increase 
fish survival in the wild. Test on salmonids showed that exposure to such conditions increases the ability of fish to feed on novel prey (Brown et al. 2003) and increased survival after restocking in semi-natural conditions (Maynard et al. 1996). These results could be explained by the improvement of cognitive efficiency and behavioral flexibility as proven in other reintroduced animal groups (Hunter et al. 2002; Rabin 2003).

Studies using enriched rearing conditions need to be specifically designed for the fish species studied, because the ways they can be improved largely depend on the species' sensitivity to environmental conditions, i.e. phenotypic plasticity. In previous studies, the majority of data obtained is related to species of commercial interest (i.e. salmonids), and were gathered under controlled conditions (Braithwaite and Salvanes 2005; Salvanes and Braithwaite 2006). However, there should be more research into the effects of enriched environment on fish performance (growth, survival and swimming capacities) under natural conditions and on other fish species. For fish species in reintroduction programs, as is the case of the European sturgeon, there is a real need to understand how rearing conditions of artificially reproduced larvae can affect life history and performance traits that will directly impact fish fitness once released into the wild (Chebanov et al. 2011). Fish performance is the product of a combination of environmental and genetic effects (Dammerman et al. 2015). The program's European sturgeon broodstock is small, i.e. few numbers of spawners and not all fish are ready to reproduce every year, and breeding of genetic dissimilar individuals may not be enough to guarantee good offspring quality, since genetic quality (additive and non-additive genetic effects) is not assessed (Neff and Pitcher 2005; Pitcher and Neff 2007). Paternal effects on early life history success may be more important than previously thought, and may also merit more extensive investigation (Rideout et al. 2004).

The aim of the present study was to assess the effects of enriched rearing on the survival, growth and behavioral performance of three-month-old sturgeons belonging to two different crossings. This particular life stage was chosen because it is one of the preferred stages used for stocking in the Gironde.

\section{Materials and methods}

Fish

Fish specimens used in this experiment came from the French captive stock, and experiments were carried out at the Irstea experimentation station in St Seurin sur l'Isle. Fish for this study were raised between June and September 2014, from six days post-hatch (dph) until 92 dph (three-month old). Fish originated from assisted fecundation of a single female with two males $(\mathrm{C} 1=$ crossing male $1, \mathrm{C} 2=$ crossing male 2 ) (Chèvre et al. 2011). These wild-born spawners were chosen based on availability and their characteristics are described in Table 1.

\section{Rearing conditions}

Two sets of rearing conditions were tested: enriched and traditional. Two hundred and fifty larvae from each crossing were reared under each set of conditions ( $n=500$ larvae per rearing conditions). During the first month, for each rearing environment, larvae from each crossing were reared separately in hatching tanks (raceways $135 \times 50 \times 22 \mathrm{~cm}$; length* width*height; water level $=15 \mathrm{~cm}$, two raceways per rearing condition). Later, 50 fish of each crossing $(n=100$ per rearing conditions) were randomly chosen, mixed and reared together in larger tanks (two replica per rearing condition) until they were three months old. To identify their

Table 1 Spawners characteristics

\begin{tabular}{llllll}
\hline Sex & Cohort & Capture year & $\begin{array}{l}\text { Time in captivity } \\
\text { (years })\end{array}$ & $\begin{array}{l}\text { Weight } \\
(\mathrm{kg})\end{array}$ & $\begin{array}{l}\text { Total length } \\
(\mathrm{cm})\end{array}$ \\
\hline Female $^{1}$ & 1994 & 2003 & 11 & 29.4 & 169 \\
${\text { Male } 1^{2}}^{2}$ & 1994 & 1995 & 19 & 12.4 & 133 \\
Male $^{3}$ & 1994 & 2002 & 12 & 27.6 & 163 \\
\hline
\end{tabular}

Fish ID: ${ }^{1} 3 \mathrm{D} 49,{ }^{2} 041121 \mathrm{E} 3 \mathrm{C} 4$, ${ }^{3} 0411285$ AA5

Fish ID: ${ }^{1} 3 \mathrm{D} 49,{ }^{2} 041121 \mathrm{E} 3 \mathrm{C} 4$,
${ }^{3} 0411285 \mathrm{AA} 5$


parental background, larvae from both crossings were marked, beneath the rostrum, using visible implant elastomer tags (VIE) (Northwest Marine Technology Inc.) (Kapusta et al. 2015) at one-month old. Based on a preliminary trial on one-month old Siberian sturgeon (Acipenser baerii), the VIE tag was expected to last two months.

Traditional rearing conditions were based on the protocol used to raise fish for stocking in the Gironde and captive stock supplementation (Chèvre et al. 2011). In this experiment, we used tanks (from month two, tanks size $120 \times 120 \times 60 \mathrm{~cm}$, water level $=40 \mathrm{~cm})$ run indoors in darkness $(0.43 \pm 0.51 \times 10 \mathrm{~lx}$, mean $\pm \mathrm{SD}$, Chauvin Arnoux luxmeter DA815) with a flow-through system of underground water. Tank conditions were maintained at a constant temperature of $18.4 \pm 0.2^{\circ} \mathrm{C}$ and $30 \%$ of water renewal per hour. Temperature and oxygen $(>90 \%)$ were recorded automatically once every 5 min with an automatic computerized system (WTW ${ }^{\mathrm{TM}}$ devices). Additionally, ammonium $(0.1 \mathrm{mg} /$ 1), nitrites $(0.02 \mathrm{mg} / \mathrm{l})$, nitrates $(1.5 \pm 0.84 \mathrm{mg} / \mathrm{l})$ levels (Visocolor ${ }^{\circledR}$ ECO test kit) and $\mathrm{pH}(7.7 \pm 0.12)$ were registered weekly. Fish were fed ad libitum with live artemia (Artemia salina) since 9 dph for 12 days, a mix of artemia and unfrozen bloodworms (Chironomus sp.) for nine more days and then only bloodworms as mentioned in Chèvre et al. (2011). Tanks were cleaned twice per day by flushing water away.

Enriched rearing conditions consisted of small mesocosms imitating the variability of the natural environment. Spatial cues were added and manipulated.
Tanks were run outdoors to be subject to natural photoperiod, but covered with mesh to reduce brightness and strong light (natural $=346.6 \pm 634.0 \times 101 \mathrm{x}$; under cover $=32.6 \pm 55.9 \times 10 \mathrm{~lx}$ ) and avoid bird predation. One-month old fish were placed in $170 \times 100 \times 75 \mathrm{~cm}$ tanks (two replica, same density as in traditional rearing i.e. density $=0.2 \mathrm{fish} / \mathrm{m}^{3}$ ). A partition wall was added in the middle of the tanks to allow water current circulation using a water pump. The water supply consisted of a flow-through system of filtrated river water with the same water flow as in traditional rearing. Temperature $\left(21.5 \pm 1.5^{\circ} \mathrm{C}\right.$, Fig. 1$)$, oxygen ( $\left.>90 \%\right)$, were recorded once every $5 \mathrm{~min}$ and ammonium $(0.1 \mathrm{mg} / \mathrm{l})$, nitrites $(0.04 \pm 0.02 \mathrm{mg} / \mathrm{l})$, nitrates $(8.83 \pm 3.31 \mathrm{mg} / \mathrm{l})$ levels and $\mathrm{pH}(7.8 \pm 0.08)$ were registered weekly. During week 68 of rearing, a mix of well and river water (1:1) was used to decrease water temperature due to the high records registered on week $3-5$ (max. registered $25.8{ }^{\circ} \mathrm{C}$, Table 2, Fig. 1). Fish were fed in the same way as for traditional rearing. Landscapes were created using different elements, according to variability encountered in the river: sand (0-2 mm), fine gravel ( $8-16 \mathrm{~mm})$, coarse gravel with pebbles $(30-95 \mathrm{~mm})$ (standard A.S.T.M), artificial $\operatorname{logs}(20-30 \mathrm{~cm})$, variable water current and depth (Table 3). These cues were modified once a week and combination levels were chosen at random. Tanks were cleaned twice per day by flushing water away.

The two types of rearing environment differed in terms of temperature regime (Mann-Whitney, $\mathrm{U}=0.5$, $p<0.01$ ), nitrites (Mann-Whitney, $\mathrm{U}=3.0, \mathrm{p}<0.01$ ), and nitrates (Mann-Whitney, $\mathrm{U}=0.0, \mathrm{p}<0.01$ ), but had
Fig. 1 Mean temperature during fish rearing. Interrupted line indicates enriched rearing and continuous line traditional rearing

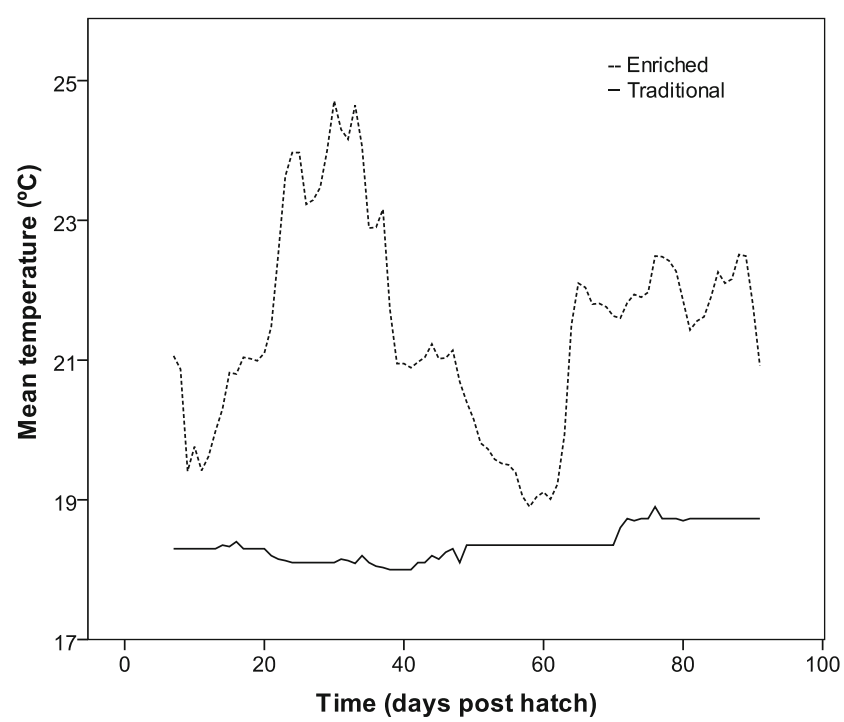


Table 2 Temperature in enriched rearing condition

\begin{tabular}{lllll}
\hline Week & Min $\left({ }^{\circ} \mathrm{C}\right)$ & $\operatorname{Max}\left({ }^{\circ} \mathrm{C}\right)$ & Daily mean $\left({ }^{\circ} \mathrm{C}\right)$ & Standard deviation \\
\hline 1 (1-7 July ) & 18.5 & 21.6 & 19.9 & 0.7 \\
2 (8-14 July) & 18.8 & 22.0 & 20.8 & 0.5 \\
3 (15-21 July) & 20.0 & 24.9 & 23.1 & 1.1 \\
4 (22-28 July) & 22.6 & 25.8 & 24.1 & 0.7 \\
5 (29 July -4 August) & 20.3 & 24.1 & 21.9 & 1.0 \\
6 (5-11 August) & 20.1 & 21.7 & 21.0 & 0.3 \\
7 (12-18 August) & 19.0 & 20.6 & 19.8 & 0.3 \\
8 (19-25 August) & 18.3 & 19.7 & 19.1 & 0.3 \\
9 (26 August - 1 September) & 19.3 & 22.7 & 21.6 & 0.7 \\
10 (2-8 September) & 20.5 & 23.1 & 21.9 & 0.6 \\
11 (9-15 September) & 20.4 & 23.1 & 21.9 & 0.6 \\
12 (16-24 September) & 19.8 & 23.0 & 21.8 & 0.7 \\
\hline
\end{tabular}

similar levels of ammonium (Mann-Whitney, $\mathrm{U}=18$, $p=1$ ) and $\mathrm{pH}$ (Mann-Whitney, $\mathrm{U}=2.0, p=0.63$ ) features.

Growth, survival and pigmentation.

Each month, the total number of live fish per crossing per tank was counted to assess the mortality rate for each treatment (two crossings $\mathrm{x}$ two rearing methods). Mortality was determined monthly as: Mortality $(\%)=($ number of dead fish / total number of fish) $* 100$. Survival probability for fish on each rearing method, at the end of the experiment, was calculated as the product of each month survival probability, which was determined as: survival probability $=$ (number of live fish $/$ total number of fish). To assess growth and adjust the food ration, fish were weighed to the nearest $0.001 \mathrm{~g}$ (Sartorius Practum 513-1S) and measured for length (Mitutoyo Absolute Digimatic) individually ( $n=25$ per treatment) every week from the second week of trial (not done before due to small larvae size) until two months. During the third month, fish were measured only once at the end of the experiment to avoid handling before behavioral tests. The heterogeneity index was determined at $92 \mathrm{dph}$ as: Coefficient of variation $(\%)=($ Standard deviation $/$ mean weight) $* 100$. Observations on fish pigmentation were done empirically as an unintended outcome of the study.

\section{Behavioral tests}

To assess differences in fish cognition, behavioral tests were carried out on randomly chosen 78 dph old juveniles. A subsample of the fish was used in the two different tests. The first set up was designed to evaluate fish exploratory behavior ( $n=35$ per treatment): It was carried out in Komatex ${ }^{\circledR}$ (walls) and Plexiglas ${ }^{\circledR}$ (bottom) aquariums $(90 \times 50 \times 30 \mathrm{~cm})$ divided into three compartments (start and challenge chamber $20 \times 50 \times 30 \mathrm{~cm}$; novel chamber $50 \times 50 \times 30 \mathrm{~cm}$; Fig. 2), in dark conditions and using either well or river water depending on fish rearing condition. Water in the experimental arena was replaced between every individual to eliminate chemical cues. First, fish were placed individually in the "start chamber" for five minutes. The divider was then removed to let the fish explore the "novel" and "challenge" chambers (both connected through a semi-circle passage of $4.5 \mathrm{~cm}$ radius) for $15 \mathrm{~min}$. Behavior was video recorded (Ikegami $($ ) from above using EthoVision® XT 9 software (Noldus
Table 3 Landscape cues in the mesocosms

${ }^{1}$ water velocity varied across the water column and around the tank

\begin{tabular}{lllll}
\hline \multicolumn{2}{l}{ Water parameters } & \multicolumn{3}{l}{ Landscape } \\
\hline Level & Depth $(\mathrm{cm})$ & Average velocity $(\mathrm{cm} / \mathrm{s})^{1}$ & Logs & Substratum \\
1 & 0.70 & $8 \pm 5$ & Present & Large/medium \\
2 & 0.57 & $6 \pm 4$ & Absent & Medium/small \\
3 & 0.40 & 0 & & Large/small \\
\hline
\end{tabular}




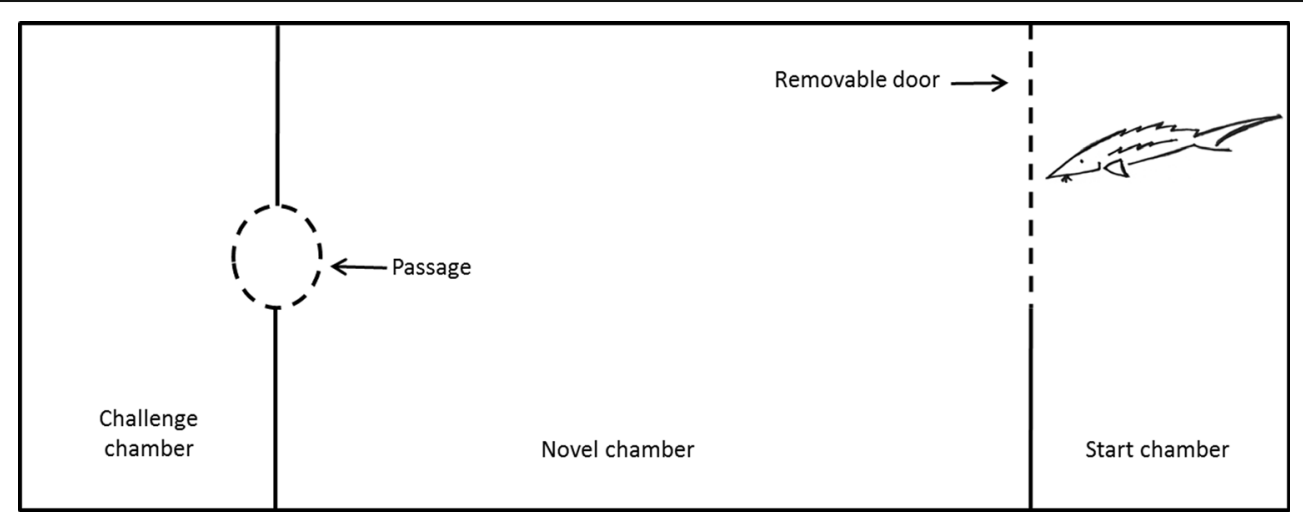

Fig. 2 Behavioral experimental arena, 3-chamber aquarium

et al. 2001) using infrared light. The measured parameters were: latency to enter and swimming speed in the "novel chamber", success (pass or not), frequency (number of successes) of movement into the "challenge chamber", latency to first enter the "challenge chamber" and success in exiting from it. After the test, every fish tested was weighed and measured for length (up to $1 \mathrm{~mm}$ ) to standardized swimming speed. The second behavioral test "novel prey" experiment was conducted after the exploration test for a subsample ( $n=20$ per treatment). This test aimed to measure the ability of individuals to feed on unknown prey. Individuals were placed in separate glass aquaria $(28 \times 19 \times 17 \mathrm{~cm})$ in darkness, using water depending on their origin, and fasted for $24 \mathrm{~h}$. Afterwards, fish were provided with 10 live white worms (Enchytraeus albidus) and given $60 \mathrm{~min}$ to feed. Success to feed (food consumed or not) and amount of prey consumed per fish were recorded. The white worms came from a local aquarium store and were unfamiliar to the fish. We choose this worm species because it has been previously recorded in the stomach contents of wild juveniles (Acolas et al. 2011c).

\section{Statistical analysis}

The $\mathrm{X}^{2}$ test of independence was used to explore differences in mortality between treatments, after determining no differences among replicas (i.e. tanks). A stepwise multinomial logistic regression model was used to assess the best predictors of growth (i.e. weight was used as proxy of growth) by testing the effects of the rearing method, crossings, replicas, and temperature. Analysis of variance and Mann-Whitney and Scheirer-Hare-Ray tests (when assumptions on normality and homoscedascity were not met) were used to compare weight and length between treatments at 14, 35, 64 and $92 \mathrm{dph}$. In addition, growth for the different treatments was compared using general lineal models (GLMs) with a Gaussian distribution considering age in accumulated thermal units to compare fish at the same ontogenic stage. Behavioral discrete data were analyzed using negative binomial and binary regressions, continuous data using Scheirer-Hare-Ray test and behavioral data correlations were analyzed using Spearman correlations as assumption on normality and homoscedascity were not met. Statistical analyses were performed using $\mathrm{R}$ statistical software (R-Core-Team 2013) and $p$-values $<0.05$ were considered significant.

\section{Results}

Survival

No fish during the experiment died or exhibited symptoms due to obvious bacterial infection or any other visible pathogen. During the first month of rearing, mortalities were observed from $12 \mathrm{dph}$ of rearing in all treatments. The mortality rate during the first month varied between $12.8 \%$ and $18 \%$, and there was no significant difference in mortality between treatments $\left(\mathrm{X}^{2}=2.05, \mathrm{df}=3, p=0.15\right)$ (Table 4). For the second month of rearing, mortality in enriched rearing was $10.15 \%$ and significantly different from the value of $0.49 \%$ obtained in traditional rearing $\left(\mathrm{X}^{2}=18.65, \mathrm{df}=1\right.$, $p<0.01$ ). In enriched rearing, a positive correlation was identified between temperature and fish deaths (Spearman, $\mathrm{rs}=0.54, p=0.04$ ). Mortality in enriched rearing conditions decreased to $1.12 \%$ during the third month, 
Table 4 Rate of monthly survival according to treatment. Replicas have been pooled together because there were no significant differences between them. Different letters represent significant differences

Survival rate $(\%)$

\begin{tabular}{lll}
\hline & Enriched & Traditional \\
Month 1 & $83.8^{\mathrm{a}}$ & $87.0^{\mathrm{a}}$ \\
Month 2 & $89.9^{\mathrm{a}}$ & $99.5^{\mathrm{b}}$ \\
Month 3 & $98.9^{\mathrm{a}}$ & $96.5^{\mathrm{a}}$ \\
\hline
\end{tabular}

and increased to $3.48 \%$ for traditional rearing, but no differences between both were found $\left(X^{2}=2.24, \mathrm{df}=1\right.$, $p=0.13$ ). Survival probability during all the experiment was higher for traditional-reared fish (0.8) than for enriched-reared fish (0.7).

\section{Growth}

For growth measurements, larvae were chosen randomly from all treatments and replicas data were pooled together because no differences between them were found. Initial weight and length were not measured because larvae were too small to be accurately measured alive. On this basis, we assume no initial difference due to random sampling in the same hatching tanks for all treatments.

The multinomial logistic regression model pointed out "rearing" and "crossing" as the best growth predictors explaining $82 \%$ of data variation (AIC $=1950.6$, Cox-Snell $=0.82$, Table 5), tank and temperature effects were not considered to be significant explanatory variables.

Differences in growth between rearing environments favored enriched rearing from $14 \mathrm{dph}$ onwards $\left(\mathrm{H}_{2}=59.7, p<0.01\right)$. Both crossings had similar body weight (Mann-Whitey; enriched, $\mathrm{U}=298.5, p=0.8$; traditional $\mathrm{U}=281.5, p=0.6$; Table 6 ) and length (one-way anova; enriched $\mathrm{F}(1,45)=0.85, p=0.36$; traditional
$\mathrm{F}(1,48)=2.87, p=0.09$; Table 6) within each rearing environment. By 35 dph until 92 dph, both crossings in enriched conditions performed similarly but their weight (Scheirer-Ray-Hare; method, $\mathrm{H}=37.1, p<0.01$; cross, $\mathrm{H}=11.4$, p < 0.01; Table 6, Fig. 3) and length (ScheirerRay-Hare; method, $\mathrm{H}=42.5, \mathrm{p}<0.01$; cross, $\mathrm{H}=8.2$, $\mathrm{p}<0.01$; Table 6) differed under traditional conditions. Moreover the final heterogeneity index was higher for traditional rearing (6 to $13 \%$ higher than in enriched condition).

Further analysis to compare juveniles of the same ontogenic stage (age expressed in degree days), was consistent with results previously obtained: similar growth for both crossings enriched rearing (GLM, $p=0.81$, Fig. 4) but different growth among crossings for traditional rearing (GLM, $\mathrm{p}<0.01$, Fig. 4). In traditional rearing, fish from crossing two showed similar growth performance to the fish from both crossings in enriched rearing (GLM, $p=0.06$, Fig. 4) for the same ontogenic stage. In traditional rearing, crossing one had the lowest growth performance of all. In addition, empirical observations on pigmentation showed that fish coloration differed between rearing conditions from 14 dph: fish reared in enriched tanks were dark colored, while traditional fish were pale, although coloration was not precisely measured.

\section{Behavior}

During exploratory tests, fish expressed different behavior according to the rearing environment. First, no differences between crossing and rearing conditions were found in latency to enter the novel chamber (ScheirerHare-Ray; method $p=0.17$, cross $p=0.11$, interaction $=0.73$ ) and in swimming speed within this novel chamber (Scheirer-Hare-Ray; method $p=0.29$, cross $p=0.3$, interaction $p=0.14$ ). Fish reared under enriched conditions took longer to enter the challenge chamber for the first time $(452 \pm 243 \mathrm{~s})$ than traditionally reared

Table 5 Multinomial logistic regression models. Rearing refers to traditional or enriched rearing conditions, crossing refers to C1 and C2 parental background and tank to replicas

\begin{tabular}{lllll}
\hline Variables & Significant variables & AIC & $p$-value & Pseudo-square (Cox-Snell) \\
\hline Rearing, crossing, tank, temperature & rearing, crossing & 2628.69 & 0.00 & 0.83 \\
Rearing, crossing, temperature & rearing, crossing & 2304.31 & 0.00 & 0.83 \\
Rearing, crossing & rearing, crossing & 1950.58 & 0.00 & 0.83 \\
\hline
\end{tabular}


Table 6 Growth performance of two crossings of juvenile European sturgeon (A. sturio) exposed to two different rearing conditions. $\mathrm{C} 1$ (male 1) and $\mathrm{C} 2$ (male 2) indicate the fish crossings.
Letters indicate, for each line of the table, the comparison between treatments: different letters represent significant differences

Traditional rearing

Enriched rearing

\begin{tabular}{lllll}
\hline Parameter & $\mathrm{C} 1$ & $\mathrm{C} 2$ & $\mathrm{C} 1$ & $\mathrm{C} 2$ \\
Weight at $14 \mathrm{dph}(\mathrm{g})$ & $0.04 \pm 0.0^{\mathrm{a}}$ & $0.04 \pm 0.0^{\mathrm{a}}$ & $0.06 \pm 0.0^{\mathrm{b}}$ & $0.06 \pm 0.0^{\mathrm{b}}$ \\
Length at $14 \mathrm{dph}(\mathrm{cm})$ & $1.9 \pm 0.0^{\mathrm{a}}$ & $1.9 \pm 0.1^{\mathrm{a}}$ & $2.1 \pm 0.1^{\mathrm{b}}$ & $2.2 \pm 0.1^{\mathrm{b}}$ \\
Weight at $35 \mathrm{dph}(\mathrm{g})$ & $0.1 \pm 0.0^{\mathrm{a}}$ & $0.3 \pm 0.1^{\mathrm{b}}$ & $0.4 \pm 0.1^{\mathrm{bc}}$ & $0.4 \pm 0.1^{\mathrm{c}}$ \\
Length at $35 \mathrm{dph}(\mathrm{cm})$ & $3.1 \pm 0.3^{\mathrm{a}}$ & $3.5 \pm 0.4^{\mathrm{b}}$ & $4.0 \pm 0.4^{\mathrm{c}}$ & $4.2 \pm 0.4^{\mathrm{c}}$ \\
Weight at $64 \mathrm{dph}(\mathrm{g})$ & $1.5 \pm 0.7^{\mathrm{a}}$ & $2.1 \pm 0.9^{\mathrm{ab}}$ & $2.9 \pm 1.2^{\mathrm{c}}$ & $2.7 \pm 1.0^{\mathrm{bc}}$ \\
Length at $64 \mathrm{dph}(\mathrm{cm})$ & $6.5 \pm 1.3^{\mathrm{a}}$ & $7.2 \pm 1.3^{\mathrm{a}}$ & $8.3 \pm 1.2^{\mathrm{b}}$ & $8.2 \pm 1.2^{\mathrm{b}}$ \\
Final weight at 92 dph $(\mathrm{g})$ & $4.4 \pm 2.0^{\mathrm{a}}$ & $7.2 \pm 2.8^{\mathrm{b}}$ & $9.6 \pm 3.0^{\mathrm{c}}$ & $9.6 \pm 3.2^{\mathrm{c}}$ \\
Final length at $92 \mathrm{dph}(\mathrm{cm})$ & $9.8 \pm 1.5^{\mathrm{a}}$ & $11.5 \pm 1.7^{\mathrm{b}}$ & $13.0 \pm 1.3^{\mathrm{c}}$ & $12.9 \pm 1.5^{\mathrm{c}}$ \\
Heterogeneity at $92 \mathrm{dph}(\%)$ & 46.7 & 39.9 & 31.9 & 33.7 \\
\hline
\end{tabular}

fish $(437 \pm 309 \mathrm{~s})$ (Scheirer-Hare-Ray, method, $\mathrm{H}=6.8$, $p=0.01$ ), but $88.4 \%$ of them engaged at least once into the challenge chamber against $67.8 \%$ of the traditionally reared fish (GLM binary logistic, $\mathrm{X}^{2}=9.1, p=0.02$;
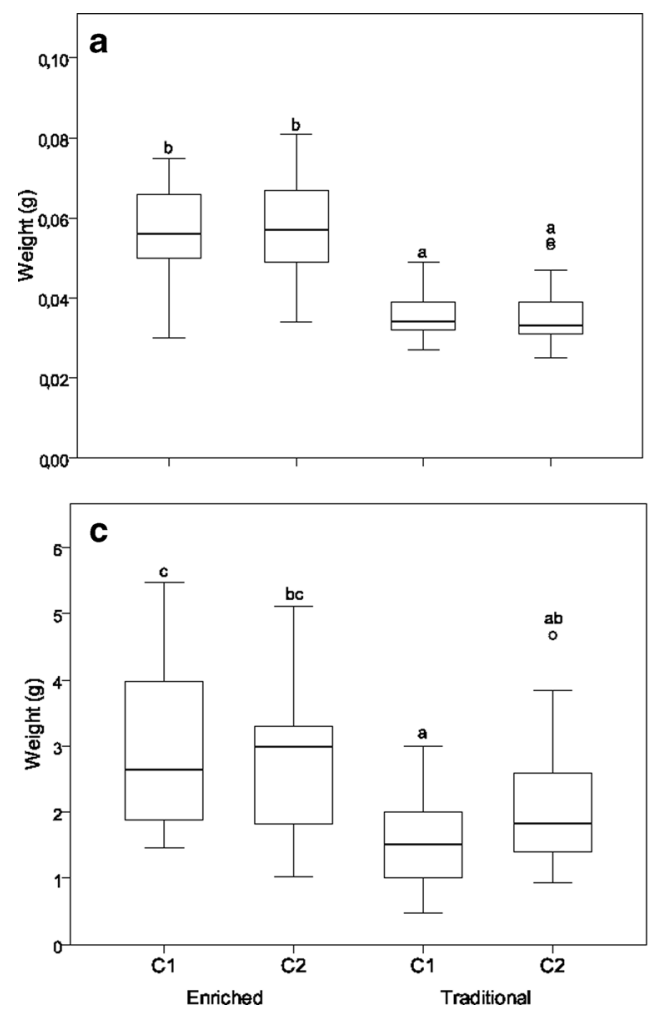

Fig. 3 Box plot of juveniles weight of two crossings (C1 and C2) of European sturgeon at (a) $14 \mathrm{dph}$, (b) $35 \mathrm{dph}$, (c) $64 \mathrm{dph}$ and (d) 92 dph reared in enriched and traditional conditions. Circles represent outliers, whiskers denote minimum and maximum method, $p<0.01)$. Considering the fish that engaged in the challenge chamber, enriched-reared fish made an average of 1.53 entries while traditional-reared fish entered an average of 1.29 times. Also, $81.1 \%$ of the
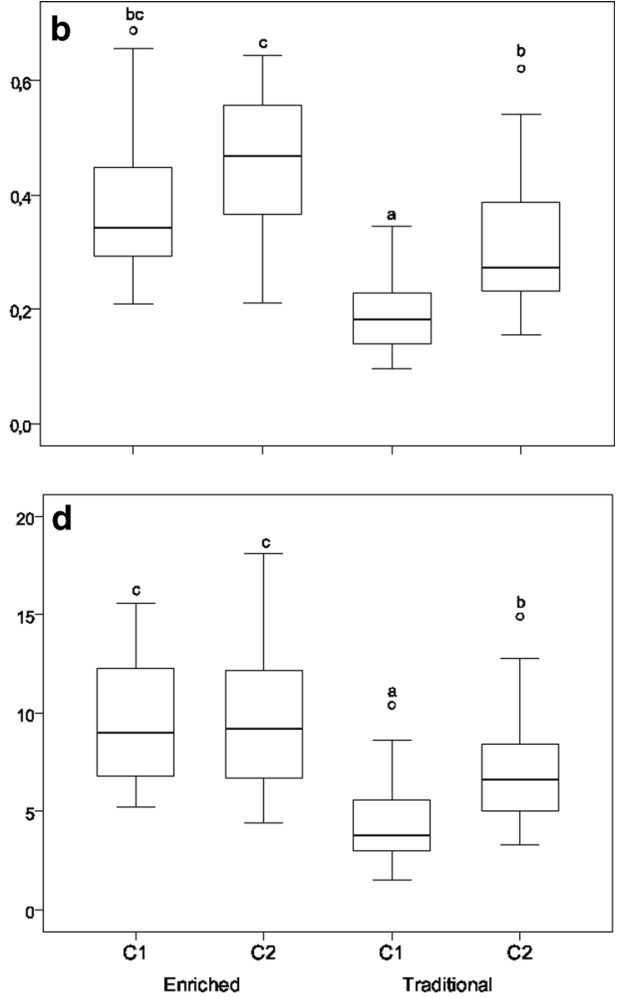

values, box indicates interquartile range and line indicates median. Within each panel, different letters represent significant differences 
Fig. 4 Juveniles growth of two crossings of European sturgeon (A. sturio) during 3 months (92 dph) of rearing in enriched and traditional methods. Interrupted lines indicate mean values and continuous lines $95 \%$ confidence intervals. $a$ ) indicate enriched rearing fish, both crossings plotted together, $b$ ) indicates $\mathrm{C} 2$ crossing in traditional rearing and $c$ ) indicates $\mathrm{C} 1$ crossing in traditional rearing

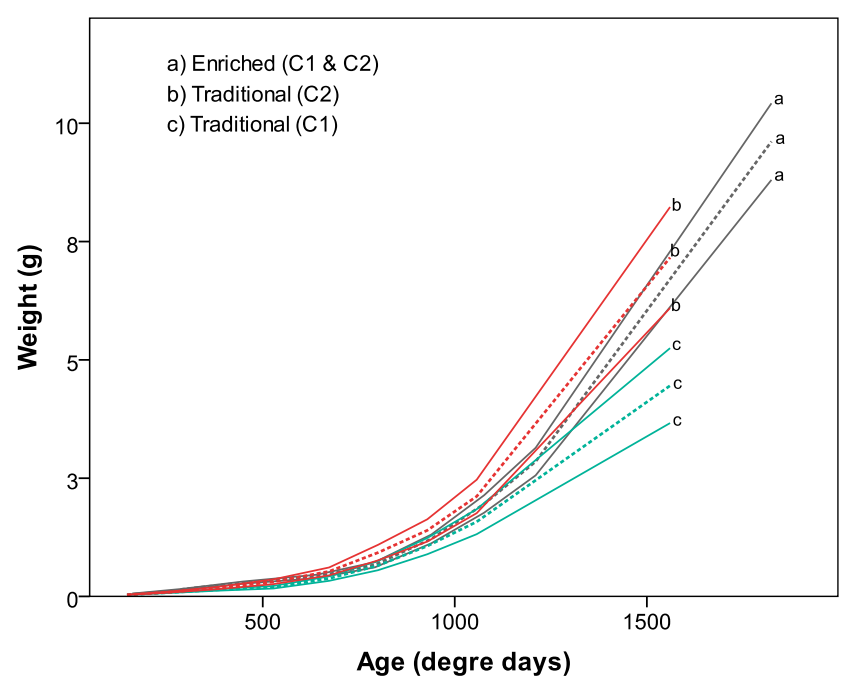

survival gives a good initial quantitative insight into the efficiency of hatchery conditions from a conservation point of view. Observed early mortality was most likely produced by the adjustment from endogenous to exogenous feeding, as reported in other sturgeon studies at similar developmental stages (Charlon and Bergot 1991; Gisbert et al. 2000; Williot et al. 2005; Boucher et al. 2014). Following the exogenous feeding transition, mortality usually declines (Gisbert et al. 2000). In our experiment, for the first and the third month of rearing, mortality rates were similar between crossings and rearing conditions, which is a promising result for the enriched rearing approach. However, we highlighted a higher mortality in enriched rearing during the second month. This can be explained by the higher water temperatures observed during the summer time. Even though the precise optimal growth temperature for juveniles of $A$. sturio is unknown, $20{ }^{\circ} \mathrm{C}$ have been reported to maximize survival, hatching and metabolism capacities on larvae of this specie (Delage et al. 2014). Deleterious effects on larvae have been seen between 23 and $26^{\circ} \mathrm{C}$, (Delage et al. 2014). These results suggest that survival during the first three months can be impacted by temperature. Enriched rearing, as proposed in this study, can be a promising approach as long as the river water temperature can be maintained below $23{ }^{\circ} \mathrm{C}$ as high mortality was not observed below this temperature.

The growth of fish in rearing conditions is another key life history trait considered by aquaculture practice studies. During rearing of larvae, many biotic (parental effects, genetic background, density, hierarchical
When breeding fish for stocking purposes, it is important to optimize early stage survival in order to reduce the early mortality that would otherwise occur in the wild due to predation, starvation or disease. Fish 
interactions) (Huntingford et al. 2012) and abiotic parameters (temperature, salinity, $\mathrm{pH}$, etc.) (Stickney 2005) are intensively studied to create an optimal setup for fish growth. We found that growth performance of European sturgeon juveniles was influenced by crossing and rearing methods. However, temperature is one of the factors included in the "rearing method". When comparing growth, achieved in different conditions at the same number of $\mathrm{dph}$, temperature variation could partly explain these differences, since temperature is known to have a significant influence on fish growth (Jobling 2002). Separating the effects of each parameter was not the goal of this study but to test how environmental heterogeneity could affect fitness-related traits instead. In our study, fish in enriched environment tended to grow better than those reared in traditional hatchery conditions. All the parameters used in enriched conditions were expected to have a positive impact on fish performance. In different species, it has been demonstrated that a minimal light threshold is required to develop and grow correctly (Boeuf and Le Bail 1999). In sturgeons, photoperiod treatment increases fish growth rates and weight gain compared with fish reared in darkness (Ruchin 2007; Ghomi et al. 2010; Kryuchkov and Obukhov 2010, as cited in Ghomi et al. 2010). Differences in fish growth in enriched rearing could also be explained by substrate occurrence. For example, white sturgeon larvae reared on substrate resulted in improved growth and survival and these effects remained after larvae were transferred to a bare environment (Boucher et al. 2014). Such observations have been attributed to reduction in fish activity and stress (Boucher et al. 2014) because substrate provides shelter. Better growth of enriched-reared fish can also be explained by exercise conditioning caused by water currents. Some studies suggest that the effects of training on fish significantly increase final weight, growth rates and food conversion efficiency (Young and Cech Young and Cech 1993; Davison 1997). This is explained by an increment in muscular development and heart performance that can be beneficial in stocking programs because it might improve survival in the wild (Young and Cech Young and Cech 1993; Davison 1997). Being bigger can also improve survival in the wild (Hutchings 2002; Wilke et al. 2014) because bigger fish have wider size ranges of prey items and have a lower predation risk than smaller fish (Juanes et al. 2002).

When analyzing juvenile growth at the same developmental stage we highlighted that one crossing performed differently depending on its rearing environment. This result might be explained by interaction between genotype and the environment. Based on hematological indices, hatchery settings can be considered as unnatural and stressful environment (Ruchin 2007; Grant 2015). Exposure to stress can separate genotypes according to their capacity to cope with it (Wu et al. 2003), which can explain the differences in growth of both fish crossings and the higher heterogeneity in traditional rearing. Within the spawners, male 1 was the smallest with the longest time in captivity and the lowest growth performance in captivity (12.2 kg vs $27.6 \mathrm{~kg}$ for male two of the same age). This could suggest maladaptation to captivity conditions; a tendency which appears to be mirrored through its offspring which perform better in enriched environments (phenotypic plasticity) (West-Eberhard 2003; Monaghan 2008). To be able to conclude on this genotype-environment interaction on European sturgeon, more families for common garden experiment studies are needed in the future.

In addition to the well-established parameters (i.e. survival and growth) directly assessed on fish during the rearing period, other characteristics could play an important role in their fitness once released in the wild. For example, body pigmentation may provide with good camouflage within the environment, reducing predation risk and increasing survival (Svanbäck and Eklöv 2011). In sturgeons, it is believed that body pigmentation is linked to behavioral traits and early life foraging and migration (Kynard et al. 2005). We observed differences in pigmentation that may be caused by the light differences between both methods and they could have a significant influence on habitat-specific fitness of individuals after release. Another aspect to highlight is the homing behavior occurring in anadromous species (McDowall 2001; Metcalfe et al. 2002). Sturgeon is considered to have strong homing skills, although there are few data regarding their imprinting and homing processes (Bemis and Kynard 1997; Waldman and Wirgin 1998). Nevertheless, given the homing behavior of other migratory fish groups such as salmonids (Metcalfe et al. 2002), there is likelihood that hatchery-reared sturgeons may exhibit a higher straying rate than wild counterparts if the imprinting occurs at an early stage. In this regard, rearing fish using water from the release-sites, as in the present study, may produce better-imprinted fish than those produced in well water that is not found in the wild. In addition, rearing on release-site water may overcome the 
introduction of parasite-naïve individuals that can fail to join the natural population due to local pathogens as have been documented previously (Work et al. 2000; Antolin et al. 2002).

Individual fish behavior may play an important role in fish survival in the wild. Indeed, individual response to challenging environments (e.g. stress coping style) which correspond to potentially risky situations can have a direct consequence on fish survival or growth by influencing fish physiological and behavioral state (Wingfield 2003; Øverli et al. 2007). Habitat heterogeneity promotes behavioral flexibility (i.e. ability to adjust their behavior to the new conditions) (Braithwaite and Salvanes 2005; Salvanes et al. 2007; Kotrschal and Taborsky 2010) and exploratory behavior (Nilsson et al. 1999; Zimmermann et al. 2001; Braithwaite and Salvanes 2005) required to deal with unpredictable environmental conditions as the conditions found in the wild. In our study, we found that more individuals from enriched rearing entered the challenge zone of our experimental device, when compared to the group of traditionally reared fish. This can be interpreted as more pronounced exploratory behavior within the individuals reared in enriched environment and corroborates previous studies where exploratory tendency of individuals could be a consequence of higher habitat heterogeneity (Nilsson et al. 1999; Zimmermann et al. 2001; Meehan and Mench 2002; Braithwaite and Salvanes 2005). However, we found that fish from enriched conditions took longer to enter the challenge zone. This apparently paradoxical result can be explained by higher tendency towards environmental assessment developed under enriched conditions. Indeed, it has been suggested that environmental variability improves individual reaction to novel circumstances (Meehan and Mench 2002; Salvanes et al. 2007; Strand et al. 2010). In this case, the fish require longer time lapses in order to perceive the cues, assess them and adjust the behavior accordingly. In this perspective, we could associate the fish from different rearing conditions to behavioral strategies with different stress coping style, known to have a genetic background but also to be under high influence of early life environment (Frost et al. 2007; Chapman et al. 2010; Roberts et al. 2011; Jonsson and Jonsson 2014). In this case, behavior of enriched-habitat reared fish may be better suited to the conditions found in the wild. Environmental heterogeneity also increases phenotypic variation (Crossman et al. 2014) and this is a key feature that enhance population fitness and facilitates its establishment and persistence (Whitman and Agrawal 2009; Forsman 2014; Forsman 2015). Therefore, the success of stocking programs with conservation purposes relies on genetic and phenotypic diversity (Forsman 2014) that we can promote under adaptive aquaculture approaches.

When analyzing the results on the novel prey test, no significant differences between treatments were found. We assume that this is an outcome of similar feeding protocols in both rearing environments. In enriched rearing no cues were manipulated during feeding, and unpredictability on food supply has been shown to shape behavioral traits (Chapman et al. 2010). Also, it is possible that the fish motivational state were not enough to elicit different feeding behavior. Prey characteristics as color, movement, size, shape, fish stomach fullness (Croy and Hughes 1991; Gill and Hart 1994) and prey density (Ioannou et al. 2009) have an important role on foraging behavior and our test conditions may not match the thresholds required for our species to initiate differential feeding on novel prey. However a negative correlation between latency to enter the challenge zone and amount of prey consumed was highlighted on traditional-reared fish, which is difficult to interpret with the elements we have and would require further experiments.

Overall, our results suggest that rearing conditions for fish early stages should be taken into account for stocking purposes. We found that enriched rearing conditions influence positively fitness related traits of fish such as growth and behavior. They would benefit from better growth but they would also exhibit more exploratory but cautious behavior when facing a new environment. We also suspect a genotype-environment interaction in favor of enriched rearing environment that would be promising to study on further research. These are important results that encourage enhancing fish performance within restocking programs with enriched rearing practices.

Acknowledgments This study was funded by the Office National de l'Eau et des Milieux Aquatiques (ONEMA) and the National Research Institute of Science and Technology for Environment and Agriculture (IRSTEA). We wish to thank the personnel of Saint Seurin experimental station (IRSTEA) for their contribution in the fish rearing, Maud Pierre (IRSTEA) for her advices in statistical analysis and Alexandre Gentil for his help on video recording analysis. 


\section{Compliance with ethical standards}

Ethical approval This study was carried out in an approved experimental hatchery facility by the French Department of Agriculture (authorization A33-478-001) and was revised by the regional ethic committee of animal use for scientific purposes.

Open Access This article is distributed under the terms of the Creative Commons Attribution 4.0 International License (http:// creativecommons.org/licenses/by/4.0/), which permits unrestricted use, distribution, and reproduction in any medium, provided you give appropriate credit to the original author(s) and the source, provide a link to the Creative Commons license, and indicate if changes were made.

\section{References}

Aarestrup K, Jepsen N, Koed A, Pedersen S (2005) Movement and mortality of stocked brown trout in a stream. J Fish Biol 66: $721-728$

Acolas ML, Castelnaud G, Lepage M, Rochard E (2011a) Biological cycles and migrations of Acipenser sturio. In: Williot P, Rochard E, Desse-Berset N, Kirschbaum F, Gessner J (eds) Biology and conservation of the European sturgeon Acipenser sturio L 1758. Springer, Germany, pp. $147-152$

Acolas ML, Gessner J, Rochard E (2011b) Population conservation requires improved understanding of in situ life histories. In: Williot P, Rochard E, Desse-Berset N, Kirschbaum F, Gessner J (eds) Biology and conservation of the European sturgeon Acipenser sturio L 1758. Springer, Germany, pp. 585-592

Acolas ML, Roqueplo C, Rouleau E, Rochard E (2011c) Post release monitoring techniques. In: Williot $\mathrm{P}$, Rochard $\mathrm{E}$, Desse-Berset N, Kirschbaum F, Gessner J (eds) Biology and conservation of the European sturgeon Acipenser sturio L 1758 Springer, Germany, 407-416.

Acolas ML, Rochard E, Le Pichon C, Rouleau E (2012) Downstream migration patterns of one-year-old hatcheryreared European sturgeon (Acipenser sturio. J Exp Mar Biol Ecol:430-431

Adams SR, Parsons GR, Hoover JJ, Killgore KJ (1997) Observations of swimming ability in shovelnose sturgeon (Scaphirhynchus platorynchus. J Freshw Ecol 12:631-633

Adams SR, Hoover JJ, Killgore KJ (1999) Swimming endurance of juvenile pallid sturgeon, Scaphirhynchus albus. Copeia 1999:802-807

Alvarez D, Nicieza AG (2003) Predator avoidance behaviour in wild and hatchery-reared brown trout: the role of experience and domestication. J Fish Biol 63:1565-1577

Antolin MF, et al. (2002) The influence of sylvatic plague on North American wildlife at the landscape level, with special emphasis on black-footed ferret and prairie dog conservation. In: Rahm J (ed) Transactions of the 67th North American wildlife and natural resources conference. USA
Aprahamian MW, Smith KM, McGinnity P, McKelvey S, Taylor J (2003) Restocking of salmonids - opportunities and limitations. Fish Res 62:211-227

Araki H, Berejikian BA, Ford MJ, Blouin MS (2008) Fitness of hatchery-reared salmonids in the wild. Evol Appl 1:342-355

Arlati G, Poliakova L (2009) Restoration of Adriatic sturgeon (Acipenser naccarii) in Italy: situation and perspectives. In: Carmona R, Domezain A, García-Gallego M, Hernando J, Rodríguez F, Ruiz-Rejón M (eds) Biology, conservation and sustainable development of sturgeons, Fish \& Fisheries Series, vol 29. Springer, Netherlands, pp. 237-245

Arnold SJ (1983) Morphology, performance and fitness. Am Zool 23:347-361

Bemis WE, Kynard B (1997) Sturgeon rivers: an introduction to acipenseriform biogeography and life history. Environ Biol Fish 48:167-183

Bergendahl IA, Salvanes AGV, Braithwaite VA (2016) Determining the effects of duration and recency of exposure to environmental enrichment. Appl Anim Behav Sci 176: 163-169

Billard R, Lecointre G (2000) Biology and conservation of sturgeon and paddlefish. Rev Fish Biol Fish 10:355-392

Birstein VJ (1993) Sturgeons and paddlefishes: threatened fishes in need of conservation. Conserv Biol 7:773-787

Boeuf G, Le Bail PY (1999) Does light have an influence on fish growth? Aquaculture 177:129-152

Boucher MA, McAdam SO, Shrimpton JM (2014) The effect of temperature and substrate on the growth, development and survival of larval white sturgeon. Aquaculture 430:139-148

Braithwaite VA, Salvanes AGV (2005) Environmental variability in the early rearing environment generates behaviourally flexible cod: implications for rehabilitating wild populations. Proc R Soc B Biol Sci 272:1107-1113

Brown C, Davidson T, Laland K (2003) Environmental enrichment and prior experience of live prey improve foraging behaviour in hatchery-reared Atlantic salmon. J Fish Biol 63:187-196

Busack CA, Currens KP (1995) Genetic risks and hazards in hatchery operations: fundalmental concepts and issues. Am Fish Soc Symp 15:71-80

Campton DE (1995) Genetic effects of hatchery fish on wild populations of Pacific salmon and steelhead: what do we really know? Am Fish Soc Symp 15:337-353

Castelnaud G, Rochard E, Jatteau P, Lepage M (1991) Données actuelles sur la biologie D'acipenser sturio dans l'estuarie de la Gironde. In: Williot P (ed) Acipenser. Cemagref Publ, France

Chapman BB, Morrell LJ, Krause J (2010) Unpredictability in food supply during early life influences boldness in fish. Behav Ecol 21:501-506

Charlon N, Bergot P (1991) Alimentation artificielle des larves de l'esturgeon Sibérien (Acipenser baeri, Brandt). In: Williot P (ed) Proceedings of the First International Symposium on the Sturgeon CEMAGREF, Bordeaux, France, 405-415.

Chassaing O, Desse-Berset N, Hänni C, Hughes S, Berrebi P (2016) Phylogeography of the European sturgeon (Acipenser sturio): a critically endangered species. Mol Phylogenet Evol 94(Part A):346-357

Chebanov MS, Karnaukhov GI, Galich EV, Chmir YN (2002) Hatchery stock enhancement and conservation of sturgeon, 
with an emphasis on the Azov Sea populations. J Appl Ichthyol 18:463-469

Chebanov M, et al. (2011) Sturgeon hatchery practices and management for release: guidelines. FAO Fisheries and Aquaculture Technical Paper No 570.

Chèvre P, Saint-Sevin J, Mercier D, Jacobs L, Williot P (2011) Recent progress in larval rearing of the European sturgeon, Acipenser sturio. In: Williot P, Rochard E, Desse-Berset N, Kirschbaum F, Gessner J (eds) Biology and conservation of the European sturgeon Acipenser sturio L 1758. Springer, Germany, pp. 449-453

Crossman JA, Scribner KT, Davis CA, Forsythe PS, Baker EA (2014) Survival and growth of lake sturgeon during early life stages as a function of rearing environment. Trans Am Fish Soc 143:104-116

Croy MI, Hughes RN (1991) The influence of hunger on feeding behaviour and on the acquisition of learned foraging skills by the fifteen-spined stickleback, Spinachia spinachia L. Anim Behav 41:161-170

Dammerman KJ, Steibel JP, Scribner KT (2015) Genetic and environmental components of phenotypic and behavioral trait variation during lake sturgeon (Acipenser fulvescens) early ontogeny. Environ Biol Fish 98:1659-1670

Davison W (1997) The effects of exercise training on teleost fish, a review of recent literature. Comp Biochem Physiol A Physiol 117:67-75

De Mestral LG, Herbinger CM (2013) Reduction in antipredator response detected between first and second generations of endangered juvenile Atlantic salmon Salmo salar in a captive breeding and rearing programme. J Fish Biol 83:1268-1286

Delage N, Cachot J, Rochard E, Fraty R, Jatteau P (2014) Hypoxia tolerance of European sturgeon (Acipenser sturio L., 1758) young stages at two temperatures. J Appl Ichthyol 30:11951202

Forsman A (2014) Effects of genotypic and phenotypic variation on establishment are important for conservation, invasion, and infection biology. Proc Natl Acad Sci U S A 111:302307

Forsman A (2015) Rethinking phenotypic plasticity and its consequences for individuals, populations and species. Heredity 115:276-284

Frost AJ, Winrow-Giffen A, Ashley PJ, Sneddon LU (2007) Plasticity in animal personality traits: does prior experience alter the degree of boldness? Proc R Soc Lond B Biol Sci 274:333-339

Gessner J, Tauteman M, Von Nordheim H, Borchers T (2010) Plan national d'actions pour la protection et la conservation de l'Esturgeon européen (Acipenser sturio) en Allemagne. Ministère fédéral de l'environnement de la protection de la nature et de la sureté nucléaire France

Ghomi M et al (2010) Manipulation of photoperiod in growth factors of beluga sturgeon Huso huso. Afr J Biotechnol 9: 1978-1981

Gill AB, Hart PJB (1994) Feeding behaviour and prey choice of the threespine stickleback: the interacting effects of prey size, fish size and stomach fullness. Anim Behav 47:921-932

Gisbert E, Williot P, Castelló-Orvay F (2000) Influence of egg size on growth and survival of early stages of Siberian sturgeon (Acipenser baeri) under small scale hatchery conditions. Aquaculture 183:83-94
Grant KR (2015) Fish hematology and associated disorders. Veterinary clinics of North America: exotic animal. Practice 18:83-103

Gross MR, et al. (2002) Sturgeon conservation: insights from elasticity analysis. In: Van Winkle W, Anders PJ, Secor DH, Dixon DA (eds) Biology, management and protection of North American sturgeon vol 28, USA, 13-30.

Hunter SA, Bay MS, Martin ML, Hatfield JS (2002) Behavioral effects of environmental enrichment on harbor seals (Phoca vitulina concolor) and gray seals (Halichoerus grypus. Zoo Biol 21:375-387

Huntingford F, Jobling M, Kadri S (2012) Aquaculture and behavior. John Wiley \& Sons, UK

Hutchings JA (2002) Life histories of fish. In: Hart PJB, Reynolds JD (eds) Handbook of fish biology and fisheries, vol I. Blackwell, UK, pp. 149-174

Huusko A, Vehanen T (2011) Do hatchery-reared brown trout affect the growth and habitat use of wild congeners? Fish Manag Ecol 18:258-261

Ioannou CC, Morrell LJ, Ruxton GD, Krause J (2009) The effect of prey density on predators: conspicuousness and attack success are sensitive to spatial scale. Am Nat 173:499-506

IUCN (2015) The IUCN red list of threatened species. In. www. iucnredlist.org Accessed 20 Jan 2016

IUCN/SSC (2013) Guidelines for reintroductions and other conservation translocations. Species Survival Commission, Gland, Switzerland, viiii +57

Jackson JR, VanDeValk AJ, Brooking TE, VanKeeken OA, Rudstam LG (2002) Growth and feeding dynamics of lake sturgeon, Acipenser fulvescens, in Oneida Lake, New York: results from the first five years of a restoration program. J Appl Ichthyol 18:439-443

Jager HI (2005) Genetic and demographic implications of aquaculture in white sturgeon (Acipenser transmontanus) conservation. Can J Fish Aquat Sci 62:1733-1745

Jobling M (2002) Environmental factors and rates of development and growth handbook of fish biology and fisheries. Vol I. Blackwell 97-122.

Johnson JL, Hintz WD, Garvey JE, Phelps QE, Tripp SJ (2014) Evaluating growth, survival and swimming performance to determine the feasibility of telemetry for age- 0 pallid sturgeon (Scaphirhynchus albus. Am Midl Nat 171:68-77

Johnsson JI, Brockmark S, Näslund J (2014) Environmental effects on behavioural development consequences for fitness of captive-reared fishes in the wild. J Fish Biol 85:1946-1971

Jonsson B, Jonsson N (2014) Early environment influences later performance in fishes. J Fish Biol 85:151-188

Juanes F, Buckel JA, Scharf FS (2002) Feeding ecology of piscivorous fishes. In: Hart PJB, Reynolds JD (eds) Handbook of fish biology and fisheries vol I Blackwell UK, 267-283.

Kapusta A, Duda A, Wiszniewski G, Kolman R (2015) Preliminary evaluation of the effectiveness of visible implant elastomer and coded wire tags for tagging young-of-the-year Atlantic sturgeon, Acipenser oxyrinchus. Archives of Polish Fisheries 23(p):227

Klefoth T, Pieterek T, Arlinghaus R (2012) Impacts of domestication on angling vulnerability of common carp, Cyprinus carpio: the role of learning, foraging behaviour and food preferences. Fish Manag Ecol 20:174-186

Kotrschal A, Taborsky B (2010) Environmental change enhances cognitive abilities in fish. PLoS Biol 8:e1000351 
Kynard B, Parker E, Parker T (2005) Behavior of early life intervals of Klamath River green sturgeon, Acipenser medirostris, with a note on body color. Environ Biol Fish 72:85-97

Lamaze FC, Sauvage C, Marie A, Garant D, Bernatchez L (2012) Dynamics of introgressive hybridization assessed by SNP population genomics of coding genes in stocked brook charr (Salvelinus fontinalis. Mol Ecol 21:2877-2895

Lassalle G, Crouzet P, Gessner J, Rochard E (2010) Global warming impacts and conservation responses for the critically endangered European Atlantic sturgeon. Biol Conserv 143:2441-2452

Lepage M, Rochard E (1995) Threatened fishes of the world: Acipenser sturio Linnaeus, 1758 (Acipenseridae. Environ Biol Fish 43:28-28

Maltsev SA (2009) Conservation of the sturgeon fish in lower Volga. In: Carmona R, Domezain A, García-Gallego M, Hernando JA, Rodríguez F, Ruiz-Rejón M (eds) Biology, conservation and sustainable development of sturgeons, Fish \& Fisheries Series, vol 29. Springer, Netherlands, pp. 265-273

Massee KC, Kim J, Berejikian BA, Hardy RW (2007) Prey selection and efficiency of naïve and experienced juvenile sockeye salmon. J Fish Biol 70:1213-1223

Maynard DJ, Flagg TA, Mahnken CVW.,Schroder SL (1996) Natural rearing technologies for increasing postrelease survival of hatchery-reared salmon. Bulletin of the National Research Institute of Aquaculture Supplement 2:71-77.

Maynard-Smith J (1989) Evolutionary genetics. Oxford University Press, UK

McDowall (2001) Anadromy and homing: two life-history traits with adaptive synergies in salmonid fishes? Fish Fish 2:7885

MEDDTL (Ministère de l'écologie du développement durable des transports et du logement) (2011) Plan national d'actions en faveur de l'esturgeon européen Acipenser sturio.2011-2015: $69 p$.

Meehan CL, Mench JA (2002) Environmental enrichment affects the fear and exploratory responses to novelty of young Amazon parrots. Appl Anim Behav Sci 79:75-88

Metcalfe J, Arnold G, McDowall R (2002) Migration. In: Hart PJB, Reynolds JD (eds) Handbook of fish biology and fisheries vol I. Blackwell, UK, pp. 175-199

Monaghan P (2008) Early growth conditions, phenotypic development and environmental change. Philosophical transactions of the Royal Society of London B. Biological Sciences 363:1635-1645

Neff BD, Pitcher TE (2005) Genetic quality and sexual selection: an integrated framework for good genes and compatible genes. Mol Ecol 14:19-38

Nilsson M, Perfilieva E, Johansson U, Orwar O, Eriksson PS (1999) Enriched environment increases neurogenesis in the adult rat dentate gyrus and improves spatial memory. J Neurobiol 39:569-578

Noldus LPJJ, Spink AJ, Tegelenbosch RAJ (2001) EthoVision: a versatile video tracking system for automation of behavioral experiments. Behav Res Methods Instrum Comput 33:398414

Øverli Ø et al (2007) Evolutionary background for stress-coping styles: relationships between physiological, behavioral, and cognitive traits in non-mammalian vertebrates. Neurosci Biobehav Rev 31:396-412

Pitcher TE, Neff BD (2007) Genetic quality and offspring performance in Chinook salmon: implications for supportive breeding. Conserv Genet 8:607-616

Rabin LA (2003) Maintaining behavioural diversity in captivity for conservation: natural behaviour management. Anim Welf 12:85-94

R Core Team (2013) R: a language and environment for statistical computing $\mathrm{R}$ foundation for statistical computing, Vienna, Austria. URL https://www.r-project.org/

Rideout RM, Trippel EA, Litvak MK (2004) Paternal effects on haddock early life history traits. J Fish Biol 64:695-701

Roberts LJ, Taylor J, Garcia de Leaniz C (2011) Environmental enrichment reduces maladaptive risk-taking behavior in salmon reared for conservation. Biol Conserv 144:19721979

Roberts LJ, Taylor J, Gough PJ, Forman DW, Garcia de Leaniz C (2014) Silver spoons in the rough: can environmental enrichment improve survival of hatchery Atlantic salmon Salmo salar in the wild? J Fish Biol 85:1972-1991

Rochard E, Castelnaud G, Lepage M (1990) Sturgeons (Pisces: Acipenseridae); threats and prospects. J Fish Biol 37:123132

Rochard E, Lepage M, Dumont P, Tremblay S, Gazeau C (2001) Downstream migration of juvenile European sturgeon Acipenser sturio L. In the Gironde estuary. Estuaries 24: $108-115$

Rosenthal H, Bronzi P, Gessner J, Moreau D, Rochard E (2007) Action plan for the conservation and restoration of the European sturgeon. Council of Europe Publishing, France

Ruchin AB (2007) Effect of photoperiod on growth, physiologica and hematological indices of juvenile Siberian sturgeon Acipenser baerii. Biol Bull 34:583-589

Salvanes AG, Braithwaite V (2006) The need to understand the behaviour of fish reared for mariculture or restocking. J Mar Sci 63:9-9

Salvanes AGV, Moberg O, Braithwaite VA (2007) Effects of early experience on group behaviour in fish. Anim Behav 74:805811

Secor DH, Anders PJ, Van Winkle W, Dixon DA (2002) Can we study sturgeons to extinction? What we do and don't know about the conservation of North American sturgeons. In: Van Winkle W, Anders PJ, Secor DH, DA D (eds) Biology, management and protection of North American sturgeon, vol 28. American Fisheries Society, USA, pp. 3-12

Stamps JA (2007) Growth-mortality tradeoffs and "personality traits' in animals. Ecol Lett 10:355-363

Stickney RR (2005) Aquaculture: An Introductory Text. CABI, UK

Strand DA, Utne-Palm AC, Jakobsen PJ, Braithwaite VA, Jensen $\mathrm{KH}$, Salvanes AGV (2010) Enrichment promotes learning in fish. Mar Ecol Prog Ser 412:273-282

Sundström LF, Johnsson JI (2001) Experience and social environment influence the ability of young brown trout to forage on live novel prey. Anim Behav 61:249-255

Susnik S, Berrebi P, Dove P, Hansen MM, Snoj A (2004) Genetic introgression between wild and stocked salmonids and the prospects for using molecular markers in population rehabilitation: the case of the Adriatic grayling (Thymallus thymallus L. 1785. Heredity 93:273-282 
Svanbäck R, Eklöv P (2011) Catch me if you can-predation affects divergence in a polyphenic species. Evolution; International Journal of Organic Evolution 65:3515-3526

Waldman JR, Wirgin II (1998) Status and restoration options for Atlantic sturgeon in North America. Conserv Biol 12:631638

West-Eberhard MJ (2003) Developmental plasticity and evolution. Oxford University Press USA

Whitman DW, Agrawal AA (2009) What is phenotypic plasticity and why is it important? In: Whitman DW, Ananthakrishnan TN (eds) Phenotypic plasticity of insects. Science Publishers, USA, pp. 1-63

Wilke NF, O'Reilly PT, MacDonald D, Fleming IA (2014) Can conservation-oriented, captive breeding limit behavioural and growth divergence between offspring of wild and captive origin Atlantic salmon (Salmo salar). Ecol Freshw Fish. doi: 10.1111/eff. 12148

Williot P, Brun R, Rouault T, Pelard M, Mercier D (2005) Attempts at larval rearing of the endangered western European sturgeon, Acipenser sturio L. (Acipensesridae), in France. Cybium 29:381-387

Williot P, Rochard E, Rouault T, Kirschbaum F (2009) Acipenser sturio recovery research actions in France. In: Carmona R, Domezain A, García-Gallego M, Hernando J, Rodríguez F, Ruiz-Rejón M (eds) Biology, conservation and sustainable development of sturgeons, Fish \& Fisheries Series, vol 29. Springer, Netherlands, pp. 247-263

Wingfield JC (2003) Control of behavioural strategies for capricious environments. Anim Behav 66:807-816

Work TM et al (2000) Fatal toxoplasmosis in free-ranging endangered 'Alala from Hawaii. J Wildl Dis 36:205-212

Wu F, Zhang G, Dominy P (2003) Four barley genotypes respond differently to cadmium: lipid peroxidation and activities of antioxidant capacity. Environ Exp Bot 50: $67-78$

Yokota M, Harada Y, lizuka M (2003) Genetic drift in a hatchery and the maintenance of genetic diversity in hatchery-wild systems. Fish Sci 69:101-109

Young PS, Cech J Jr (1993) Improved growth, swimming performance, and muscular development in exercise-conditioned young-of-the-year striped bass (Morone saxatilis). Can J Fish Aquat Sci 50:703-707

Zhu B et al (2002) Analysis of genetic variation in the Chinese sturgeon, Acipenser sinensis: estimating the contribution of artificially produced larvae in a wild population. J Appl Ichthyol 18:301-306

Zimmermann A, Stauffacher M, Langhans W, Würbel H (2001) Enrichment-dependent differences in novelty exploration in rats can be explained by habituation. Behav Brain Res 121:11-20 